\author{
КОГЕРЕНТНІСТЬ \\ СТИМУЛЮВАННЯ ТА \\ ПІДВИЩЕННЯ ЯКОСТІ ПРАЦІ \\ ОБСЛУГОВУЮЧОГО \\ ПЕРСОНАЛУ ПІДПРИЕМСТВ \\ РЕСТОРАННОГО \\ ГОСПОДАРСТВА
}

\author{
COHERENCE STIMULATION \\ OF IMPROVEMENT THE \\ QUALITY LABOR OF \\ RESTAURANTS SERVICE \\ STAFF
}

ЛОХМАН Н. В., доктор економічних наук, доцент, завідувач кафедри економіки та бізнесу, Донецький національний університет економіки і торгівлі імені Мхайла Туган-

Барановського, КОРНІЛОВА О. В., кандидат економічних наук, доцент, доцент кафедри управління персоналом та економіки підприємства, Донецький державний університет управління

\section{LOKHMAN N.,}

Doctor of Science in Economics, Docent, Head of the Department of Economics and Business, Donetsk National University of Economics and Trade named after Mykhailo Tugan-Baranovsky, KORNILOVA O., PhD in Economics, Associate Professor of the Department of HR Management and Business Economics, Donetsk State University of Management

Досліджено поняття якості обслуговуючого персоналу підприємств ресторанного господарства. Запропоновано використовувати засоби матеріального стимулювання для підвищення якості праці обслуговуючого персоналу, а само, надбавки, преміі, бонуси. Рекомендовано для систематизації факторів впливу на рівень якості прачі обслуговуючого персоналу підприємств ресторанного господарства застосовувати діаграму К. Ісікави.

Ключові слова: якість прачі, обслуговуючий персонал, стимулювання, фактори, показники, характеристики.

Проведено исследование понятия качества обслуживающего персонала предприятий ресторанного хозяйства. Предложено использовать средства материального стимулирования для повышения качества труда обслуживающего персонала такие, как надбавки, премии, бонусы. Рекомендовано для систиматизации факторов влияния на уровень качества труда обслуживающего персонала предприятий ресторанного хозяйства использовать диаграму К. Исикавы.

Ключевые слова: качество труда, обслуживаюший персонал, стимулирование, факторы, показатели, характеристики.

The concept of quality of staff serving in the restaurant economy enterprises was researched. It is proposed to use the means of material 
incentives to improve the quality of work of service personnel such as allowances, bonuses. It is recommended to use $K$. Ishikawa diagram for systematization of factors of influence on a level of quality of work of the staff of the enterprises of restaurant economy.

Key words: quality of work, staff, stimulation, factors, indicators, characteristics.

Постановка проблеми. Зміни, які відбуваються у світової та вітчизняної економіки посилюють значення саме галузей споживання. Тому підприємства ресторанного господарства займають, безумовно, визначні позиції серед підприємств сфери харчування та гостинності. Саме постійний розвиток цих підприємств та якості їх послуг є свідченням зростання гідного рівня життя в країні. Сьогодні підприємства ресторанного господарства все більше уваги приділяють відстеженню та аналізу якості послуг обслуговуючого персоналу. Глобалізація світової економіки та спрямування України у світове економічне співтовариство також зумовлюють необхідність формування відповідної оцінки якості праці працівників ресторанного бізнесу взаємоузгодження та вдосконалення чинної системи управління якістю, яка б сприяла підвищенню якості праці обслуговуючого персоналу та гармонізації розвитку підприємств ресторанного господарства [1, с. 64].

Дослідження якості праці працівників підприємства повинно проходити в режимі постійно діючого моніторингу виявлення ключових факторів впливу на зростання якості праці окремих категорій працівників підприємств ресторанного господарства. Характеристика когерентності, як принципу, який полягає в твердженні, що все існуюче перебуває у взаємозв'язку, забезпечує визначення взаємозв'язку та взаємодії стимулювання працівників із підвищенням якості праці обслуговуючого персоналу підприємств ресторанного господарства.

Аналіз останніх досліджень $i$ публікаџій. Питанням управління якістю приділено увагу в роботах зарубіжних учених Джон Р. Уокера, Р. Форда, Дж. Аутри, К. Ісікави, [2; 3; 4; 5]. Із сучасних українських науковців проблеми якості праці досліджували О. Момот [6], Д. В. Нагернюк [7], А. М. Расулова [8], В. Г. Топольник [9], Л. В. Фролова [10], Г. Т. П’ятницъка [11], Г. С. Жуйков [12] та інш.

Невирішені питання. Недостатність наукових досліджень щодо проблем підвищення якості праці працівників, взагалі, та окремо обслуговуючого персоналу підприємств ресторанного господарства.

Mema cmammi полягає в обгрунтуванні когерентності стимулювання та підвищення якості праці обслуговуючого персоналу підприємств ресторанного господарства.

Методи дослідження. Вирішення поставлених у статті завдань здійснено за допомогою таких загальнонаукових прийомів і методів дослідження таких як аналізу і синтезу, індукції і дедукції, для деталізації об’єкта і предмета дослідження використано графічний метод та системний підхід.

Виклад основного матеріалу дослідження. Якість обслуговування відіграє значну роль в підвищенні іміджу та конкурентоспроможності будь-якого підприємства ресторанного господарства. Якість обслуговування в кафе, ресторані повинна відповідати вимогам його відвідувачів, як постійним, так і 
потенціальним. Саме обслуговуючий персонал, з яким спілкуються відвідувачі, створює той рівень обслуговування який може приваблювати більше відвідувачів, в порівнянні з підприємствами - конкурентами [8].

До групи обслуговуючого персоналу відносять: адміністратор (метрдотель), офіціанти (III, IV, V розрядів), бармен, бариста, швейцар, гардеробник [9].

3 підвищенням попиту на електронне замовлення в Інтернеті готової їжі споживачами потребує формування у закладах ресторанного господарства спеціального обслуговуючого персоналу з обслуговуванням таких замовлень [1].

Якісні характеристики, які притаманні обслуговуючому персоналу підприємств ресторанного господарства, в першу чергу, складаються з переліку ключових критеріїв - його професійних навичок та вмінь. При цьому необхідно визначити пріоритетність кожної $з$ якостей, виділяючи також обов'язкові та бажані якості.

Як правило, будь-яка професійна діяльність вимагає застосування певних особистісних рис. Крім того, для працівників обслуговуючої сфери такі особистісні професійно-поведінкові якості іноді стають найголовніші.

Набір якостей обслуговуючого персоналу ресторанного господарства слід досліджувати з урахуванням задач, які виконуються згідно з посадою, що займає працівник. Так, наприклад, відносно ключових характеристик якості праці обслуговуючого персоналу, як офіціант, слід використовувати такі показники, як швидкість обслуговування, уважність, точний i швидкий розрахунок з відвідувачами та ін.

Інформація, що міститься в нормативних документах України, а саме Національному стандарті України - ДСТУ 4281-2004 «Заклади ресторанного господарства. Класифікація», та в посадових інструкцій для обслуговуючого персоналу підприємств ресторанного господарства розробленими різними установами, має детальний опис об'єкту, та ключових характеристик закладів ресторанного господарства та організації їх діяльності [11].

Обираючи компетенції для оцінки якості праці обслуговуючого персоналу слід враховувати, що праця цього персоналу відтворюється у послугах, які ними надаються. Якщо основною послугою обслуговуючого персоналу виступає максимальне задоволення потреб споживачів при організації харчування, то набір компетенцій якості праці даної групи персоналу, буде містити тільки ті показники та критерії, які допомагають реалізувати головне завдання.

Основними характеристиками якості праці працівника обслуговуючого персоналу є:

- рівень професійної підготовки і кваліфікації;

- знання і дотримання професійної етики поведінки;

- знання нормативних і керівних документів, що стосуються професійної діяльності;

- знання i дотримання посадових інструкцій i правил внутрішнього розпорядку підприємства;

- дотримання вимог санітарії, правил особистої гігієни і гігієни робочого місця; 
- знання і дотримання заходів пожежної безпеки, правил охорони праці i техніки безпеки;

- володіння загальною культурою, дотримання професійної етики в процесі обслуговування споживачів;

- знання вимог нормативних документів на продукцію i послуги ресторанного господарства.

Таким чином, якість обслуговуючого персоналу ресторанів визначається як набір його професійних та особистісних компетенцій та залученим досвідом.

Велику роль в організації якісної роботи обслуговуючого персоналу належить метрдотелеві. Якість обслуговування залежить не тільки від науково обгрунтованої чисельності обслуговуючого персоналу в залах ресторанів, кафе i барів, але від якісних характеристик самого персоналу. Офіціанти - це найбільша за чисельністю категорія обслуговуючого персоналу саме чисельність якої безпосередньо залежить від кількості місць обслуговування та площі торгового залу [12].

Офіціант має володіти такими якісними характеристиками: вміння слухати і чути, не нав'язуючи свої рішення, люб'язність, знання психології, доброзичливість, чемність, відмінне знання меню і технології приготування страв та напоїв, ввічливість, комунікабельність, акуратність, наявність почуття власної гідності, вміння контролювати свої емоції, здатність подати себе, витриманість тощо. Офіціант повинен знати все меню, всі страви, пропоновані гостям. Основою трудової діяльності офіціанта є спілкування з відвідувачами. Офіціант повинен усвідомлювати, що його праця потрібна людям i, що його професія цінується в суспільстві, адже він $є$ важливою частиною всього складного ланцюга від приготування страв до подачі їх відвідувачам. На рис. 1 представлено показники якості праці обслуговуючого персоналу за професією «Офіціант».

Практика господарської діяльності виробила велику кількість економічних стимулів праці, які можна застосовувати в підприємствах ресторанного господарства для стимулювання праці обслуговуючого персоналу. Практика роботи підприємств свідчить, що недостатня матеріальна мотивація персоналу знижує доходи підприємства.

Відповідно необхідно ставити цілі для персоналу і визначати нагороди за їх досягнення [6].

Офіціант буде отримувати більше заохочення, якщо буде мати кращі якісні характеристики, наприклад, добре володіти іноземними мовами, знання інгредієнтів страви, способу іiі приготування, смаку, вміння запропонувати елітний алкоголь і отримати згоду відвідувача. Але всі ці навички отримує офіціант, як ще в процесі навчання, так і в період практичної діяльності і підвищення кваліфікації. Якісне навчання сприяе професійному зростанню персоналу і служить хорошою формою мотивації [7].

Стимулювати підвищення якості праці обслуговуючого персоналу можна здійснювати за допомогою надбавок за особисті досягнення в роботі, за складність та напруженість праці, виконання особливо відповідальної роботи, VIP обслуговування. Всі надбавки встановлюються персонально і на певний час, але не повинна перевищувати 20\% від суми тарифної ставки [13]. 


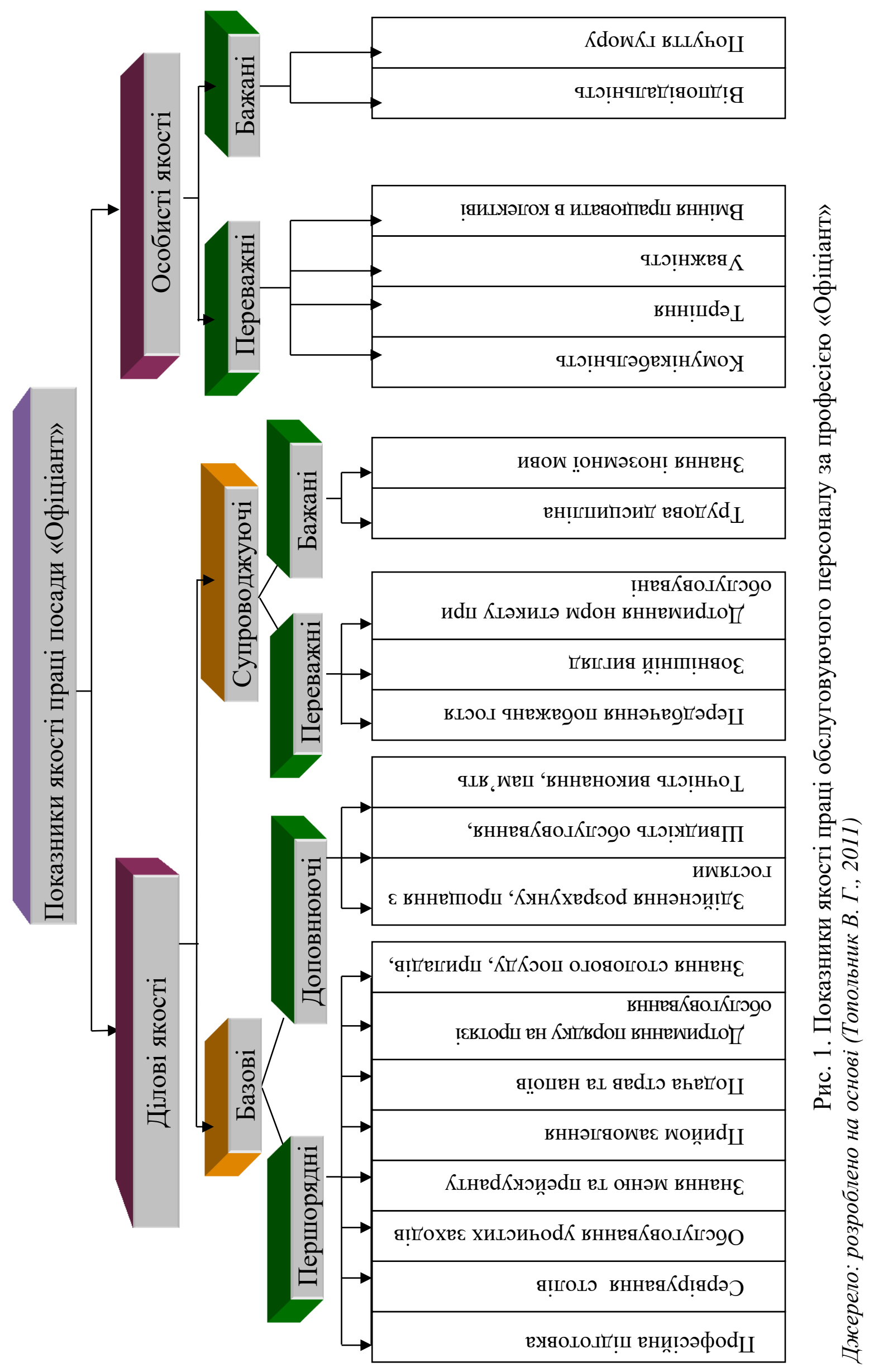


Надбавка офіціантам, барменам, бариста за високу професійну майстерність може встановлюватись від 10 до 50\% тарифної ставки за фактично відпрацьований час, виходячи зі ступеню впливу результатів праці працівника на кінцеві результати роботи підприємства. Особливістю стимулювання офіціанта та бариста $\epsilon$ можливість застосування бонусів, які $\epsilon$ негарантованими винагородами і визначаються керівниками підприємства, впродовж проведення моніторингу якості персоналу [2].

При визначенні чинників, що впливають на певний результативний показник, що характеризує якість, можна запропонувати використовувати діаграму К. Ісікави. Робоча назва діаграми - «причини i результати», або діаграма «риб'ячий кістяк» [5]. Діаграма К. Ісікави відносно факторів впливу на підвищення якості обслуговуючого персоналу підприємства ресторанного господарства представлено на рис. 2.

До факторів впливу на якість обслуговуючого персоналу впливають внутрішні і зовнішні фактори. До зовнішніх факторів відносяться зміна чисельності персоналу, рівень доходів населення, рівень цін на послуги та сировину. До внутрішніх факторів може бути обрані фактори професійні навички та особистісні характеристики. Причому кожен з видів факторів може бути більш деталізований на діаграмі більш дрібними кістками (стрілками). В якості результативного показника на діаграмі представлено якість праці (ЯП).

Представлений метод урахування чинників підвищення якості роботи обслуговуючого персоналу може застосовуватись також i при аналізі ефективності роботи підприємства ресторанного господарства.

Підвищення якості праці обслуговуючого персоналу підприємств ресторанного господарства $\epsilon$ динамічним процесом, в наслідок чого, дослідження якості праці працівників підприємства повинно проходити в режимі постійного моніторингу виявлення ключових факторів впливу на зростання якості праці окремих категорій працівників.

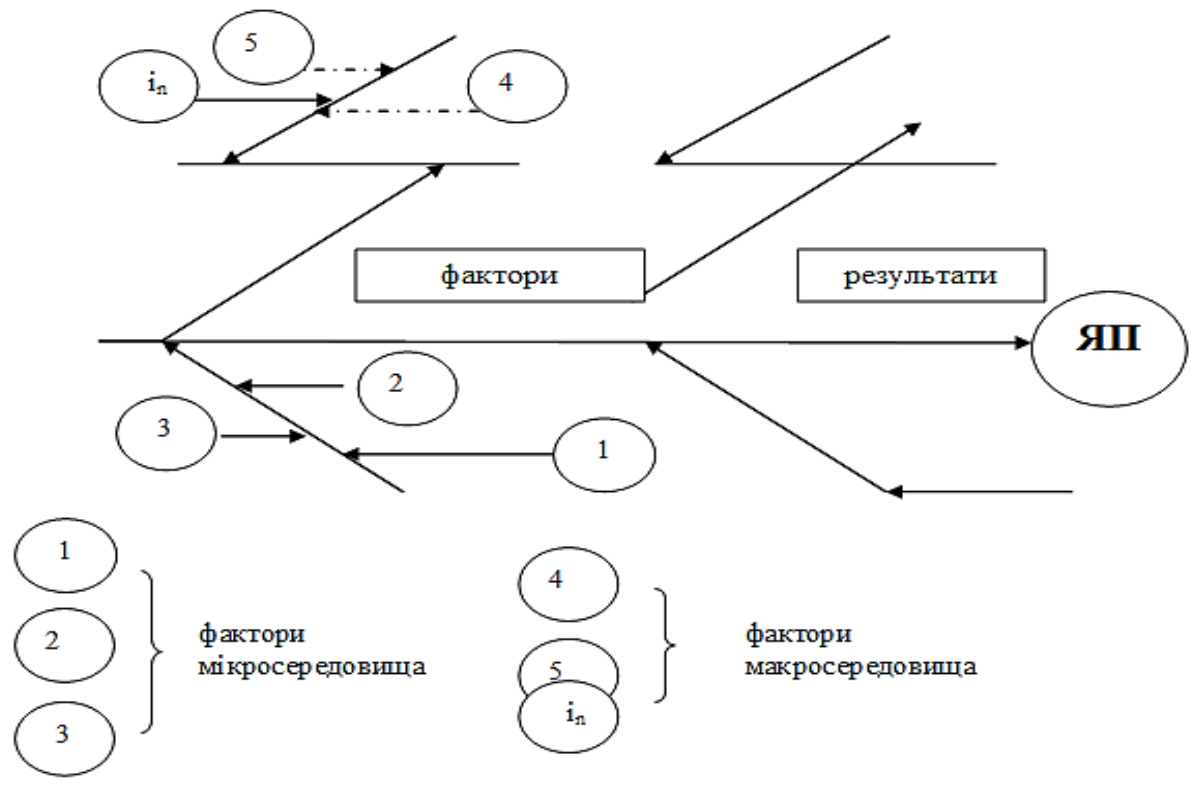

Рис. 2. Діаграма К. Ісікави відносно факторів впливу на підвищення якості обслуговуючого персоналу підприємства ресторанного господарства Джерело: розроблено на основі (Ishikawa K, 1985) 
Висновки та перспективи подальших досліджень. Варто зазначити, що підвищення якості праці $\epsilon$ важливим, як для підприємства ресторанного господарства, так i для самих працівників. Тому важливим $є$ організація ефективного стимулювання персоналу 3 приводу підвищення його якісних характеристик. При організації стимулювання праці обслуговуючого персоналу підприємства повинна ураховуватися специфіка сфери їх діяльності.

Запропоновано для визначення чинників, що впливають на якість праці обслуговуючого персоналу підприємств ресторанного господарства використовувати діаграму К. Ісікави. Це дозволить ефективніше реагувати на зміну умов підвищення (або зменшення) якості цієї категорії персоналу.

Jimepamypa:

1. Орленко О.В., Жуйков Г. Є. Економічні передумови розвитку ринку гастрономічних послуг та нові ресторанні тренди. Бізнес-навігатор. 2017. Вип. 2 (41). URL: http://www.business-navigator.ks.ua/journals/2017/41__2017/ 07.pdf.

2. Уокер Джон Р. Введение в гостеприимство. / Пер. с англ. Москва: ЮНИТИ, 1999. 463 с.

3. Ford, R., Sturman, M., \& Heaton, Ch. (2012). Managing Quality Service in Hospitality. Delmar, CENGAGE Learning.

4. Autry, J. (2004). The Servant Leader. How to Build a Creative Team, Develop Great Morale, and Improve Bottom-Line Performance. Crown Business.

5. Ishikawa, K. (1985) What Is Total Quality Control? The Japanese Way. Translated by Lu, D. J., Prentice-Hall, Englewood Cliffs, New Jersey. URL. https://www.scirp.org/(S(vtj3fa45qm1 ean45vvffcz55))/reference/ReferencesPapers.as px?ReferenceID=1932466. chb. 2020.03.22.

6. Момот О. Менеджмент якості та елементи системи якості. Київ: Центр навчальної літератури, 2007. 368 с.

7. Нагернюк Д. В. Основні чинники, що формують конкурентоспроможність підприємств ресторанного господарства. Ефективна економіка 2016. № 9. URL: http://www.economy.nayka.com.ua/?op=1\&z=5142.

8. Расулова А. М. Роль персоналу в забезпеченні конкурентоспроможності ресторану. Вісник ДонДУЕТ. Серія Економічні науки. 2004. № 3 (23). С. 174-180.

9. Топольник В.Г. Оцінка персоналу ресторанного господарства: монографія. Топольник В. Г. та ін. Донецьк: ДонДУЕТ, 2011. 272 с.

10. Фролова Л. В., Дибок В. Д. Проектування системи управління якістю обслуговуючого персоналу підприємств ресторанного господарства. Mechanism of Economic Regulation. 2014. № 3. С. 63-71.

11. ДСТУ 4281:2004. Заклади ресторанного господарства. Класифікація. Наказ Держпоживстандарту України від 31.03.2004 № 59. URL:https://dnaop. com/html/34057/doc-ДСТУ_4281_2004.

12. Чижиков В. М., Чижиков В. В. Теория и практика социокультурного менеджмента. Москва: МГУКИ, 2008. 142 с.

13. П’ятницька Г.Т. Ресторанне господарство України: ринкові трансформації, інноваційний розвиток, структурна переорієнтація: монографія. K.: KHTEУ, 2007.465 c. 


\section{References:}

1. Orlenko O. V., Zhujkov Gh. Je. Ekonomichni peredumovy rozvytku rynku ghastronomichnykh poslugh ta novi restoranni trendy. Biznes-navighator. 2017. Vyp. 2 (41). URL: http://www.business-navigator.ks.ua/journals/2017/41_ 2017/07.pdf

2. Uoker Dzhon R. Vvedenie v gostepriimstvo. Per. s angl. Moskva: JuNITI, 1999. $463 \mathrm{~s}$.

3. Ford, R., Sturman, M., \& Heaton, Ch.(2012). Managing Quality Service in Hospitality. Delmar, CENGAGE Learning.

4. Autry, J. (2004). The Servant Leader. How to Build a Creative Team, Develop Great Morale, and Improve Bottom-Line Performance. Crown Business.

5. Ishikawa, K. (1985) What Is Total Quality Control? The Japanese Way. Translated by Lu, D. J., Prentice-Hall, Englewood Cliffs, New Jersey. URL. https://www.scirp.org/(S(vtj3fa45qm1ean45vvffcz55))/reference/ReferencesPapers.as px?ReferenceID=1932466. chb. 2020.03.22.

6. Momot O. Menedzhment jakosti ta elementy systemy jakosti. Kyjiv: Centr navchaljnoji literatury, 2007. $368 \mathrm{~s}$.

7. Naghernjuk D. V. Osnovni chynnyky, shho formujutj konkurentospromozhnistj pidpryjemstv restorannogho ghospodarstva. Efektyvna ekonomika 2016. \# 9. URL: http://www.economy.nayka.com.ua/?op=1\&z=5142.

8. Rasulova A. M. Rolj personalu v zabezpechenni konkurentospromozhnosti restoranu. Visnyk DonDUET. Serija Ekonomichni nauky. 2004. \# 3 (23). S. 174-180.

9. Topoljnyk V. Gh. Ocinka personalu restorannogho ghospodarstva: monoghrafija. Topoljnyk V. Gh. ta in. Donecjk: DonDUET, 2011. 272 s.

10. Frolova L. V., Dybok V. D. Proektuvannja systemy upravlinnja jakistju obslughovujuchogho personalu pidpryjemstv restorannogho ghospodarstva. Mechanism of Economic Regulation. 2014. \# 3. S.63-71.

11. DSTU 4281:2004. Zaklady restorannogho ghospodarstva. Klasyfikacija. Nakaz Derzhpozhyvstandartu Ukrajiny vid 31.03.2004 \#59. URL:https://dnaop. com/html/34057/doc-DSTU_4281_2004.

12. Chizhikov V. M., Chizhikov V. V. Teorija i praktika sociokul'turnogo menedzhmenta. Moskva: MGUKI, 2008. $142 \mathrm{~s}$.

13 P'jatnycjka Gh. T. Restoranne ghospodarstvo Ukrajiny: rynkovi transformaciji, innovacijnyj rozvytok, strukturna pereorijentacija: monoghrafija. K.: KNTEU, $2007.465 \mathrm{~s}$.

In market condition the distribution of the service industry is the most developed in Ukraine and in the world. It is the constant development of restaurant enterprises and the quality of their services that is evidence of the growth of wealth in the country. To date, the restaurant industry pays special attention to the accounting and analysis of the quality of service staff. At all stages of the development of restaurant enterprises, studies should be carried out on the influence of factors on improving the quality of a work of staff. Based on the foregoing, it is proposed to use incentive tools to improve the quality of a work of individual employees of catering enterprises. 
The main objective of this work is to substantiate the coherence of stimulation to improve the quality labor of restaurant service staff. Methods of research. Making decisions in the article of tasks carried out using such generally available research methods and methods as analysis and synthesis, induction and deduction, the graphic method and systematic approach are used to detail the object and subject of research. Results. The concept of the quality of employees of catering enterprises was defined. The basic structure of the service personnel of restaurant enterprises and their quality characteristics was presented. It is proposed to use means of material incentives to improve the quality of work of service personnel such as allowances, bonuses. The diagram of K.Ishikawa recommended to use for systematization of factors of influence on the level of quality of work of service personnel of restaurant enterprises. Conclusions. It should be pointed out that improving the quality of labor is determined both for the restaurant enterprise and for the employees themselves. Therefore, it is important to organize effective incentives for staff to improve their quality characteristics. When organizing incentives for the staff of the enterprise should take into account the specifics of the scope of their activities. 